Bol. Inst. Oceanogr. Venezuela, Univ. Oriente 41 (1\&2): 15-24 (2002); 7 Figs., 2Tabs.

\title{
ENVIRONMENTAL CONDITIONS OF THE WATERS OF THE MANZANARES RIVER, CUMANA-SUCRE, VENEZUELA.
}

\author{
A. Márquez, W. Senior, G. Martínez, and J. Castañeda \\ Instituto Oceanográfico de Venequela, Universidad de Oriente, Cumaná, Venequela. \\ aristide@sucre.udo.edu.ve.; wsenior@sucre.udo.edu.ve.;gmartine@sucre.udo.edu.ve.
}

\begin{abstract}
The Manzanares River is one of the more important rivers of Venezuela inasmuch as it is used to supply drinking water to a large part of the northeastern zone of Venezuela. For this reason a study was undertaken of the surface waters of the estuarine zone of the river, following the saline gradient from zero to salinities greater than 30 . The following properties were measured: river volume flow, rainfall, $\mathrm{pH}$, temperature, suspended materials, dissolved oxygen and ammonium, and heavy metals $(\mathrm{Fe}, \mathrm{Mn}, \mathrm{Cu}, \mathrm{Zn}, \mathrm{Ni}, \mathrm{Cr}, \mathrm{Pb}$ and $\mathrm{Cd}$ ) in particulate and dissolved phases. River volume flow varied with seasonal rainfall throughout the year, as expected, while temperature varied between 24.5 and $30.4{ }^{\circ} \mathrm{C}$ and $\mathrm{pH}$ ranged from 6.65 and 8.9. From the dry to the wet season, suspended material increased from 23 to $880 \mathrm{mg} / \mathrm{l}$ at low salinity, and always decreased progressively as salinity increased. Concentrations of total ammonium, 14.5 to $14.3 \mathrm{mmol} / \mathrm{l}$, were high, while those of dissolved oxygen, 3.57 to $5.27 \mathrm{ml} / 1$, were low, and these levels were even more accentuated at salinities under 5 during the dry season. The highest concentrations found for heavy metals were: $\mathrm{Fe} 406.02 ; \mathrm{Mn}$ 5.57; $\mathrm{Zn} 2.18$; $\mathrm{Cu} 0.72 ; \mathrm{Cr} 0.19$; Ni 0.72; Pb 0.12; Cd $0.03 \mathrm{mmol} / \mathrm{l}$. These surpass Venezuelan legal limits for water intended for human consumption as well as for waters to be discharged in coastal areas. Concentrations decreased at increased salinity because of the dilution effect, flocculation and/or precipitation in the form of oxyhydroxides. The results obtained in this study reveal a serious deterioration of the state of the waters of the lower Manzanares river.
\end{abstract}

Key words: Contamination, surface water, estuarine zone, Venezuela.

RESUMEN: El río Manzanares es uno de los ríos más importantes de Venezuela ya que sus aguas se usan para abastecer de agua potable a la zona nororiental de Venezuela. En vista de la importancia de este río, se emprendió un estudio de las propiedades siguientes: el flujo de volumen del río, lluvia, $\mathrm{pH}$, temperatura, material en suspensión, oxígeno disuelto, amonio y metales pesados (Fe, $\mathrm{Mn}, \mathrm{Cu}, \mathrm{Zn}, \mathrm{Ni}, \mathrm{Cr}, \mathrm{Pb}$ y $\mathrm{Cd}$ ) en las fases disuelta y particulada de sus aguas, siguiendo el gradiente salina desde cero hasta salinidades mayores a 30 en las aguas superficiales de la pluma que forma. El flujo de volumen del río siguió la intensidad de lluvia, la temperatura y $\mathrm{pH}$ variaron respectivamente entre 30,4 y $24,5^{\circ} \mathrm{C}$ y 6,65 y 8,9 unidades. De la estación seca a la lluviosa, el material suspendido aumentó de 23 a $880 \mathrm{mg} / \mathrm{l}$, disminuyendo progresivamente a lo largo de la pluma con el aumento de la salinidad. Las concentraciones de amonio total, 14,5 a $14,3 \mu \mathrm{mol} / 1$ eran altas, mientras que el oxígeno disuelto, 3,57 a $5,27 \mathrm{ml} / 1$, era bajo, y sus niveles se disminuyeron más aun a salinidades inferiores a 5 unidades durante la estación seca. Las concentraciones más altas encontradas para los metales pesados eran: Fe 406,02; Mn 5,57; Zn 2,18; Cu 0,72; Cr 0,19; Ni 0,72; Pb 0,12; Cd 0,03 $\mu \mathrm{mol} / 1$. Éstos superan los límites legales venezolanos para agua de consumo humano así como para las aguas a ser servidas en las áreas costeras. Estas concentraciones disminuyeron a medida que aumentaba la salinidad debido a efectos de dilución, floculación y/o precipitación en la forma de oxihidróxidos. Los resultados obtenidos en este estudio revelan un deterioro del estado de las aguas de la cuenca baja y la pluma del río Manzanares.

Palabras clave: Agua superficial, zona estuarina, Venezuela.

\section{INTRODUCTION}

The deterioration of the environment has been, during recent years, a subject of primary importance for the countries of the first world. Ironically, in Venezuela, which has been classified as one of the six "mega-diverse" countries of Latin America and is considered to be among the ten most important places of the world for the conservation of biodiversity, the debate concerning environmental problems has not been accorded the importance which it merits. After the United Nations Conference on the Environment and Development, Rio 92, there remain no doubts concerning the scientific, economic and social importance of rivers, estuaries and coastal zones (Cincin-SAin, 1993). 
Environmental problems are of such diverse natures that generally it is necessary to order them by some means in order to systematize their study. The deterioration of a hydro-resource may be a process of various phases, such that in the initial phases the causative agents of the deterioration may perhaps be detectable through appropriate analyses. If corrective action is not taken as soon as the symptoms are detected, they may grow rapidly to an alarming level and be capable of impacting the ecosystem. The development of such a hydro-resource following the application of the corrective measures will depend upon their efficacy (Emiliani, 1997). In general, any refuse which is discharged into a body of water changes the ecological equilibrium and the capacity of the receiving current to transform such refuse (FERNÁNDEZ, 1984).

The Manzanares River is one of the more important rivers of Venezuela. In its basin, which is characterized by a dry season, from December to June, and a wet season, from July to November, is found the Turimiquire dam and reservoir, which supplies water to the entire northeast region of Venezuela. This river arises in the Turimiquire hills at an altitude of over 2000 $\mathrm{m}$ above sea level and discharges into Caribbean Sea at the entrance of the Gulf of Cariaco. It exerts a great influence upon the Venezuelan coast to the west of the city of Cumaná, which is situated between $10^{\circ}$ and $10^{\circ} 30^{\prime}$

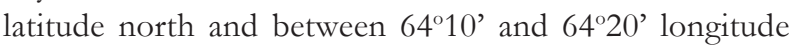
west (Figure 1). The river's hydrographic basin covers about $1,652.1 \mathrm{~km}^{2}$ and its yearly discharge is estimated at 600 million $\mathrm{m}^{3}$. In recent years this contribution has increased by more than $20 \%$ to $7711^{\prime} 10^{6} \mathrm{~m}^{3}$ (SENIOR \& Godoy, 1991; Senior, 1994; León et al., 1997; MÁrquez, 1997; Márquez et al., 2000, Martínez \& Senior, 2001). Depending on the direction of the winds and currents, the water discharged by the river into the Caribbean Sea, flows from east to west (toward the entrance to the Mochima bay) or from south to north (toward the Araya peninsula) (Mora et al., 1967). The greater portion of this current is aerobic and causes mucilages to be deposited on the sea bed, where the processes of fermentation are more frequent. At times when local industries discharge significant amounts of organic material, acids and caustic substances into the river, the mass of water undergoes changes in both its composition and its appearance, as well as the life which it sustains (FERnÁndez, 1984).
The waters of the Manzanares River drain a vast agricultural area characterized by sugar cane plantations. Studies carried out in the decade of the nineties have shown that the quality of the waters of the Manzanares River in its lower basin, from the town of Cumanacoa toward its mouth in Cumaná, has been altered as a result of increased industrial, agricultural and anthropogenic activity in the area. This is manifested as a progressive rise in the levels of organic matter, coliform organisms and heavy metals in the coastal waters near the city of Cumaná (SENIOR \& Godoy, 1991; IAbichella, 1993; León, 1995, MÁrqueZ et al., 2000).

Further details concerning the study area are described by Maloney (1966), for its geology, FERnÁNDEZ (1971, 1973, 1984), IABICHELla (1993), for bacteriological contamination, Alvarado (1976, 1979), Godoy (1991), for organic contamination, SENIOR \& Godoy (1991) for the distribution of nutritive elements, SEnIor (1994) for the environmental evaluation of the ecosystem, LEón et al. (1997), Martínez (1999) and Márquez et al. (2000) for the behavior of heavy metals in the lower basin of the Manzanares River.

The principal interest of this study is to investigate the deterioration which the waters of the Manzanares River have been experiencing. Results are presented for the superficial waters of the estuarine zone of the river during the year 1997 . The regional rainfall throughout the year is reported, as well as the volume flow rate of the river, the $\mathrm{pH}$ and temperature of its waters, and the concentrations of suspended matter, dissolved oxygen, and total ammonium and heavy metals in suspended and dissolved phases.

\section{MATERIALS AND METHODS}

A total of 22 samples of surface water of the river were collected each month during the year 1997. The samples were taken following the saline gradient from zero to salinities greater than 30 , in the direction toward the Araya peninsula (Fig.1). The salinity was measured in situ by means of a portable salinometer (YSI model 33) to a precision of \pm 0.1 , and confirmed in a separate induction unit (Kahlsico model 118 WC 200) having a precision of \pm 0.001 . 


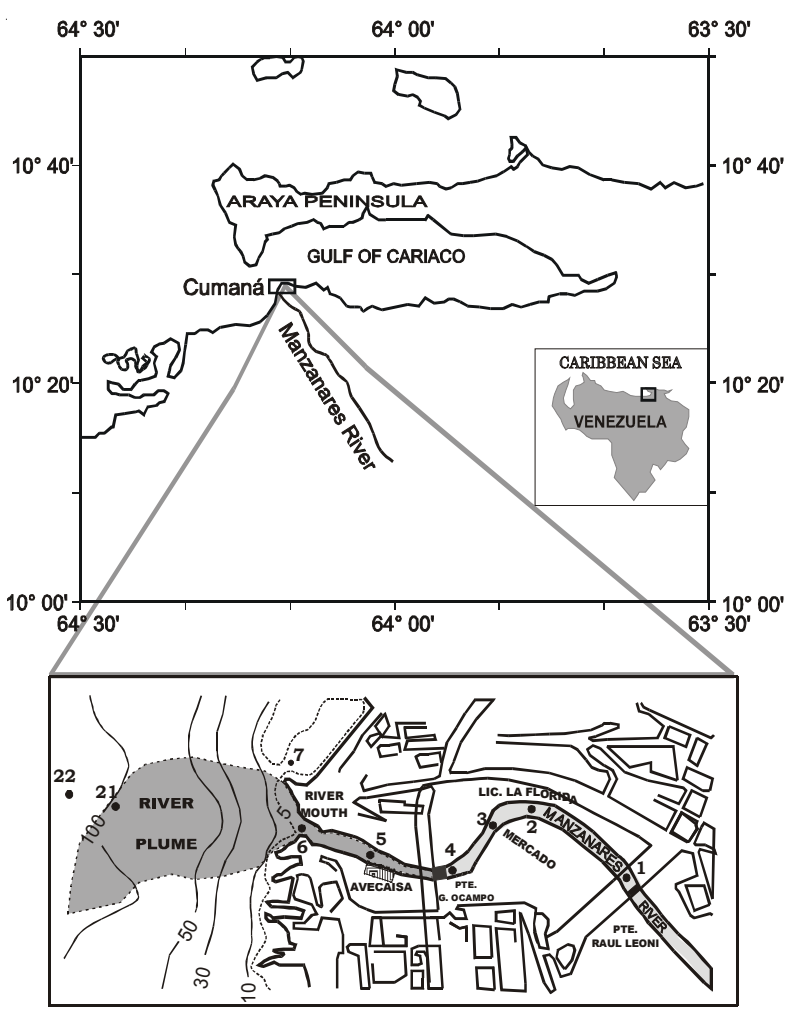

Figure 1. Sampling area, showing a section of the Manzanares river passing through the city of Cumaná

The data for the volume flow rate of the river in $\mathrm{m}^{3} /$ $\mathrm{s}$ and rainfall $(\mathrm{mm})$ were supplied by the Departamento de Hidrología y Meteorología del Ministerio del Ambiente y de los Recursos Naturales (M.A.R.N), Caracas, Venezuela. The monthly average for the period 1980-1991 for the volume flow rate at Guaripa station and for the rainfall at Salsipuedes station of the Manzanares River were used. The $\mathrm{pH}$ was determined in situ with a $\mathrm{pH}$-meter (Bantex, LCG-5) having a precision of \pm 0.01 unit. The surface temperature was determined in situ by the use of a mercury thermometer to a precision of $\pm 0.1{ }^{\circ} \mathrm{C}$. The dissolved oxygen was analyzed by the Winkler method, with a routine precision of $\pm 0.03 \mathrm{ml} / 1$ (Aмinot \& ChAussepied, 1983). Ammonium was determined according to KorolefF (1969), which measures the total ammoniac nitrogen $\mathrm{N}-\mathrm{NH}_{3}+\mathrm{N}-\mathrm{NH}_{4}{ }^{+}$. Suspended material was captured on glass filters, Gelman Science type A/E 47 $\mathrm{mm}$. The precision of this method is $\pm 0.15 \mathrm{mg} / \mathrm{l}$ and provides a limit of detection of $0.3 \mathrm{mg}$ deposited on the filter (SEnIOR, 1995). Heavy metals were determined in both particulate form and dissolved phases. For metals in the particulate phase, one liter of each sample was filtered in a Millipore apparatus, using filter membranes of cellulose type HA with pores of $0.45 \mathrm{~mm}$ in diameter. The material retained on the filter was treated with a mixture of concentrated nitric and hydrochloric acid (Greenber et al., 1992). The dissolved metals were determined from the filtrate by chelating with ammonium pirrolidine dithiocarbamate (APDC) and extracting with methyl isobutyl ketone (MIBK). The chelates in organic phase were treated with concentrated nitric and hydrochloric acid (OLSEN \& Sommerfeld, 1973; Greenber et al., 1992). The particulate and dissolved extracts were analyzed by atomic absorption spectrophotometry with an airacetylene flame in a Perkin-Elmer model 3110 instrument with deuterium background corrector. The blanks received the same treatment. The concentrations of metals allowed by Venezuelan law, which are cited in the text, are taken from the Gaceta Oficial No 34,829 of 29 January 1992.

\section{RESULTS AND DISCUSSION}

Monthly time evolution of the discharge behavior of the Manzanares River and the rainfall are shown in Figure 2, for the period 1980-1991. The values of temperature, $\mathrm{pH}$, suspended material, dissolved ammonium and oxygen are shown in Table I. The concentrations of heavy metals are presented in Table II. The behavior of the temperature and $\mathrm{pH}$ are given in Figures 3 and 4, the reduction of suspended material and heavy metals with the increase of salinity in the dry season are shown in Figures 5 and 7, respectively.

A linear relation was found with positive significance $(r=0.86)$ between the volume flow of the river and the rainfall. The flow evolved parallel with the rainfall, recording lower values $\left(8.98-15.05 \mathrm{~m}^{3} / \mathrm{s}\right.$ ) in the months of low rainfall (January to June), increasing (23.96-42.77 $\mathrm{m}^{3} / \mathrm{s}$ ) from July through November, which corresponds to the time of greatest rainfall, and then decreasing in December as the dry season begins once more. In the decade of the seventies, the values of the river flow decreased quite significantly to $14.70 \mathrm{~m}^{3} / \mathrm{s}$, which is equivalent to an annual drainage of $464 \times 10^{6} \mathrm{~m}^{3}$. This situation was made clear by Aguilera de León and Rojas (1976), who reported that 
in the year 1972 the average flow of the river was 11.75 $\mathrm{m}^{3} / \mathrm{s}$. At that time these authors pointed out the risk for the wildlife in the river. Nonetheless, in the following decades (1980-1991), according to data obtained from MARN, the waters of the river registered their greatest flow values $\left(21.99-34.05 \mathrm{~m}^{3} / \mathrm{s}\right)$, with an average of $23.17 \mathrm{~m}^{3} / \mathrm{s}$ and an annual drainage of $731 \times$ $10^{6} \mathrm{~m}^{3}$.

In spite of the fact that apparently there has been an increase in the flow of water in the river, it is worrisome that currently there is inadequate management and usage of this important fluvial body. Indiscriminate logging occurs in the higher basin and products of domestic and industrial discharge commonly become concentrated during the dry season. The small increase of average flow in recent years during the months of the dry season does not appear significant, inasmuch as the deterioration in quality of the waters has increased and the physical and chemical conditions continue to be strongly altered during the dry period of the year.

The temperature recorded during this study range between 30.4 and $24.5^{\circ} \mathrm{C}$. During the dry season, which comprises the months from February to June. Maximum values of $30.4^{\circ} \mathrm{C}$ were reached at the river upstream end in April and the minimum at the maritime edge. With the beginning of the rainy season, from August to November (Fig. 3), this situation is reversed and the

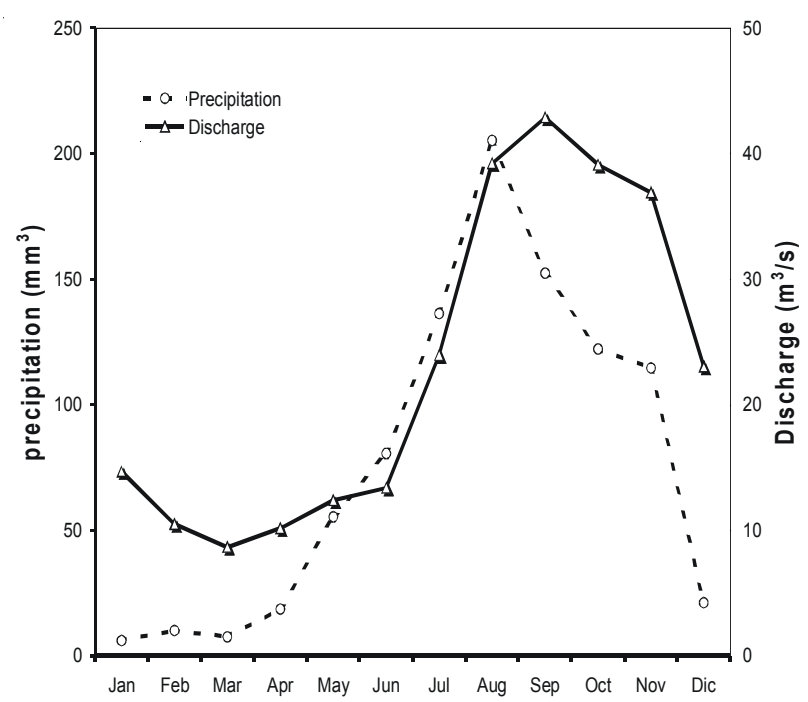

Figure. 2. Monthly averages of the annual variation of the discharge and precipitation of Manzanares River, 1980-1991. maximum temperatures are observed at the maritime edge and the minimum at the upstream end (29.0 and $25.5^{\circ} \mathrm{C}$ respectively). The low temperatures recorded in the maritime zone from February to June are associated with the coastal upwelling which affects the region (SEnior \& Godoy, 1991; Godoy, 1991; León et al., 1997; Márquez, 1997). The relaxing of this upwelling of subsurface waters during the second part of the year promotes the heating of the marine surface waters. At the same time, the river waters undergo a lowering of the temperature as a consequence of the rainfall in the higher parts of the ecosystem.

The values of $\mathrm{pH}$ generally increase with the salinity (Fig. 4), ranging from 6.65 to 8.90 and reaching its maximum of 8.90 in March. The minimum values of $\mathrm{pH}$ in the upstream extreme are principally a result of the remineralization processes of the organic matter introduced in this region of the ecosystem (Godor, 1991; León et al., 1997; MÁrquez, 1997).

The maximum concentrations of suspended matter varied between 23 and $194(\mathrm{mg} / \mathrm{l})$ in the dry season (February-June), increasing notably thereafter until reaching a maximum of $880(\mathrm{mg} / \mathrm{l})$ in the rainy season (August) (Table I). These values was observed to decline with the salinity because of a process of flocculation (MÁrquez et al., 2000) (Fig. 5). The increase of this

Figure 3. Behavior of the temperature in the surface waters of the Manzanares river, Venezuela, during the months of the dry season (-0-) and the wet season $(-\boldsymbol{\Delta}-$ ) of the year 1997. 
Table I. Values of temperatura and $\mathrm{pH}$ and ranges of concentrations of suspended material $(\mathrm{SM})$, dissólved oxygen and ammonium in the surface waters of the Manzanares river, Venezuela, during the year 1997. $\mathrm{R}=$ river end point; $\mathrm{M}=$ marine end point

\begin{tabular}{lccccc}
\hline & $\mathrm{T}\left({ }^{\circ} \mathrm{C}\right)$ & $\mathrm{pH}$ & $\mathrm{SM}(\mathrm{mg} / \mathrm{l})$ & $\mathrm{O}_{2}(\mathrm{ml} / \mathrm{l})$ & $\mathrm{NH}_{4}^{+}(\mu \mathrm{mol} / \mathrm{l})$ \\
& $\mathrm{R}-\mathrm{M}$ & $\mathrm{R}-\mathrm{M}$ & $\mathrm{R}-\mathrm{M}$ & $\mathrm{R}-\mathrm{M}$ & $\mathrm{R}-\mathrm{M}$ \\
\hline February & $27.8-24.5$ & $8.23-8.22$ & $32-2$ & $4.33-3.90$ & $14.50-4.14$ \\
March & $27.8-27.0$ & $7.70-8.90$ & $194-23$ & $4.07-4.79$ & $12.16-3.00$ \\
April & $30.4-27.2$ & $7.47-7.91$ & $155-21$ & $3.57-4.53$ & $7.70-1.91$ \\
May & $28.2-26.4$ & $7.28-8.07$ & $83-19$ & $4.02-4.75$ & $6.93-2.62$ \\
June & $29.6-26.0$ & $6.65-8.87$ & $70-13$ & $4.10-4.54$ & $14.30-0.67$ \\
August & $25.4-29.4$ & $7.36-8.47$ & $880-8$ & $4.76-5.27$ & $4.47-0.83$ \\
September & $26.8-27.1$ & $7.04-7.90$ & $115-14$ & $2.17-4.34$ & $6.78-0.40$ \\
November & $25.8-27.1$ & $7.69-8.39$ & $112-31$ & $6.20-7.89$ & $2.61-0.85$ \\
\hline
\end{tabular}

material with the beginning of the rains is associated with the erosion of the soils in the high basin of the Manzanares River, caused by activities of cutting and burning of the trees and underbrush (Aguilera et al., 1985; LEÓN et al., 1997). The high value of $194 \mathrm{mg} / \mathrm{l}$ observed in the month of March is associated with material of anthropogenic origin which is introduced into the river and/or with the resuspension of riverbed sediments, which accumulate in the period of reduced river flow and increased residence times of the waters (Márquez, 1997; Márquez et al., 2000). The concentrations reported here are lower than the 1124 and $1074 \mathrm{mg} / \mathrm{l}$ reported by LEÓN (1995) and MARTíneZ (1999) respectively in this same sampling zone.

Figure 4. Behavior of the $\mathrm{pH}$ in the surface waters of the Manzanares river, Venezuela, during the months of the dry season (-0-) and the wet season $(-\boldsymbol{\Delta} \longrightarrow)$ of the year 1997.
The maximum concentrations of ammonium varied between 14.5 and $14.3 \mathrm{mmol} / \mathrm{l}$, the lower values being found always at the maritime extreme. The highest values, observed between February and June at the upstream extreme, coincide with the period of least river flow, highest water temperature and least $\mathrm{pH}$ and dissolved oxygen concentrations, as well as the greatest residence time of the waters. These factors promote the gradual decomposition of the organic matter introduced into the river from urban waters, the Municipal Market and food processing factories located along the riverbanks in the city of Cumaná. In the study zone the ammonium would appear to have two origins: industrial and urban discharges with posterior hydrolytic liberation and through the process of decomposition of organic matter discharged into the

Table II. Maximum concentrations $(\mu \mathrm{mol} / \mathrm{l})$ of heavy metals en suspension (S), dissolved (D) and total (T) in the surface waters of the Manzanares river, Venezuela, during the year 1997. S = Metals in the particulate fraction; $\mathbf{D}=$ Metals in the dissolved fraction; $\mathbf{T}=$ Total metals $=\mathbf{S}+\mathbf{D} ;$ nd $=$ Not detected

\begin{tabular}{|c|c|c|c|c|c|c|c|c|c|}
\hline & & $\mathrm{Fe}$ & Mn & $\mathrm{Zn}$ & $\mathrm{Cu}$ & $\mathrm{Cr}$ & $\mathrm{Ni}$ & $\mathbf{P b}$ & Cd \\
\hline \multirow[t]{3}{*}{ February } & $\mathrm{s}$ & 10 & 0.13 & 0.38 & 0.02 & 0.05 & 0.14 & 0.01 & 0.004 \\
\hline & D & 0.53 & 0.03 & 0.05 & 0.01 & nd & 0.02 & nd & nd \\
\hline & $\mathrm{T}$ & 10.53 & 0.16 & 0.43 & 0.03 & 0.05 & 0.16 & 0.01 & 0.004 \\
\hline \multirow[t]{3}{*}{ March } & $\mathrm{s}$ & 123 & 1.80 & 0.36 & 0.07 & 0.07 & 0.15 & 0.03 & 0.004 \\
\hline & D & 1.65 & 0.08 & 0.06 & 0.02 & nd & 0.02 & nd & nd \\
\hline & $\mathrm{T}$ & 124.65 & 1.88 & 0.42 & 0.09 & 0.07 & 0.017 & 0.03 & 0.004 \\
\hline \multirow[t]{3}{*}{ April } & $\mathrm{s}$ & 83 & 1.18 & 0.43 & 0.10 & 0.07 & 0.13 & 0.06 & nd \\
\hline & D & 0.95 & 0.8 & 0.06 & 0.02 & nd & 0.01 & nd & nd \\
\hline & $\mathrm{T}$ & 83.95 & 1.26 & 0.49 & 0.12 & 0.07 & 0.14 & 0.06 & 0.004 \\
\hline \multirow[t]{3}{*}{ May } & $\mathrm{s}$ & 42 & 0.65 & 0.39 & 0.05 & 0.19 & 0.12 & 0.05 & nd \\
\hline & D & 0.7 & 0.04 & 0.03 & 0.01 & nd & 0.01 & nd & nd \\
\hline & $T$ & 42.07 & 0.69 & 0.42 & 0.06 & 0.19 & 0.13 & 0.05 & 0.004 \\
\hline \multirow[t]{3}{*}{ June } & $\mathrm{s}$ & 55 & 0.60 & 0.56 & 0.09 & 0.19 & 0.19 & 0.02 & 0.02 \\
\hline & D & 0.85 & 0.04 & 0.04 & 0.02 & nd & 0.02 & nd & nd \\
\hline & $\mathbf{T}$ & 55.85 & 0.64 & 0.60 & 0.11 & 0.19 & 0.21 & 0.02 & 0.02 \\
\hline \multirow[t]{3}{*}{ August } & $\mathrm{s}$ & 405.3 & 5.55 & 2.14 & 0.71 & 0.09 & 0.71 & 0.12 & 0.03 \\
\hline & D & 0.72 & 0.02 & 0.04 & 0.01 & nd & 0.01 & nd & nd \\
\hline & $\mathrm{T}$ & 406.02 & 5.57 & 2.18 & 0.72 & 0.09 & 0.72 & 0.12 & 0.03 \\
\hline \multirow[t]{3}{*}{ September } & $\mathrm{s}$ & 76.6 & 0.70 & 0.39 & 0.07 & 0.09 & 0.10 & 0.04 & 0.01 \\
\hline & D & 0.82 & 0.04 & 0.04 & 0.02 & nd & 0.01 & nd & nd \\
\hline & $\mathrm{T}$ & 80.42 & 0.74 & 0.43 & 0.09 & 0.09 & 0.11 & 0.04 & 0.01 \\
\hline \multirow[t]{3}{*}{ November } & $\mathrm{s}$ & 55 & 0.01 & 0.56 & 0.07 & 0.04 & 0.09 & 0.04 & 0.01 \\
\hline & D & 0.83 & 0.05 & 0.06 & 0.01 & nd & 0.01 & nd & nd \\
\hline & $\mathbf{T}$ & 55.83 & 1.06 & 0.60 & 0.09 & 0.04 & 0.10 & 0.04 & 0.01 \\
\hline
\end{tabular}


medium (GODOY, 1991; MÁRQUEZ, 1997). Remineralization from the decomposition of the organic matter present in the riverbed sediments is likewise not to be overlooked, inasmuch as this mechanism has been verified in the river Neckar in Germany (Song \& Müller, 1995). The concentrations of ammonium of $14.5 \mathrm{mmol} / 1$ found in the river Manzanares are alarming since normal values vary between 0.5 y $2.9 \mathrm{mmol} / 1$ in rivers (MEYBECKI, 1982) and are generally less than $1 \mathrm{mmol} / 1$ in uncontaminated coastal waters (SENIOR, 1994).

During the entire study the concentrations of dissolved oxygen remained between 3.57 and $5.27 \mathrm{ml} / 1$ until reaching a maximum level of $7.89 \mathrm{ml} / 1$ in November. Minimum concentrations of oxygen were always found at the upstream extreme. The reduction of $\mathrm{pH}$ and the increase in the concentration of ammonium at the point where the mixing of fresh and salt water begins (upstream extreme) suggest that the oxygen is being consumed by heterotrophic organisms during the process of oxidation of the organic matter which is introduced in the zone (Fig. 6). Senior \& Godoy (1991) and LeÓn (1995) indicated that the high temperatures in the first months of the year are reached in the period of least volume flow, which promotes the decomposition of the organic matter, a process which consumes much dissolved oxygen and increases the concentrations of ammonium. The concentrations of dissolved oxygen obtained in this work are below those reported for the Neckar river (Germany) (SONG \& Muller, 1995): 6.2-8.9 $\mathrm{ml} / 1$ in the summer and $8.6-11.4 \mathrm{ml} / 1$ in winter. These concentrations are worrisome inasmuch as during the decade of the seventies, concentrations between 6.8 and $9.8 \mathrm{ml} / 1$ were reported in this river (FERNÁNDEZ, 1984). Uncontaminated waters with sufficient ventilation are generally saturated with oxygen, reaching values of $8.5 \mathrm{ml} / 1$, while contaminated waters generally show an oxygen deficit, depending in large part on the content of biodegradable organic material (SENIOR, 1994). This process would appear to be occurring in the Manzanares river.

The maximum concentrations of total heavy metals were as follows: Fe 406.02; Mn 5.57; $\mathrm{Zn} \mathrm{2.18;} \mathrm{Cu} \mathrm{0.72;} \mathrm{Cr}$ 0.19; $\mathrm{Ni} 0.72$; $\mathrm{Pb} 0.12$ and $\mathrm{Cd} 0.03 \mathrm{mmol} / 1$. In suspended solids the concentrations were: $\mathrm{Fe} 405.03$; $\mathrm{Mn}$ 5.55; $\mathrm{Zn}$ 0.04; Cu 0.01; Cr 0.19; Ni 0.011; Pb 0.12 and Cd 0.03. For the dissolved phase they were: Fe 0.,72; Mn 0.,02; Zn 2.,18; $\mathrm{Cu} 0 ., 72$; Cr 0.,19 and $\mathrm{Ni} 0 ., 01 \mathrm{~m} \mathrm{~mol} / 1, \mathrm{~Pb}$ and $\mathrm{Cd}$ not being detected in this phase. All concentrations for the suspended phase were found to diminish with increasing salinity (Fig. 7), owing to processes of dilution, flocculation and/or precipitation of the suspended particles.

The maximum concentrations of all the suspended metals increased in the rainy season, with values being greatest in the month of August (Fig. 7), with the exception of chromium, which reached its greatest values in the months of May and June $(0.19 \mathrm{mmol} / \mathrm{l})$, perhaps owing to processes of dilution attributable to the increased volume flow of the river, as has been reported in the river Rhone in France (Elbaz-Poulichet et al., 1996).

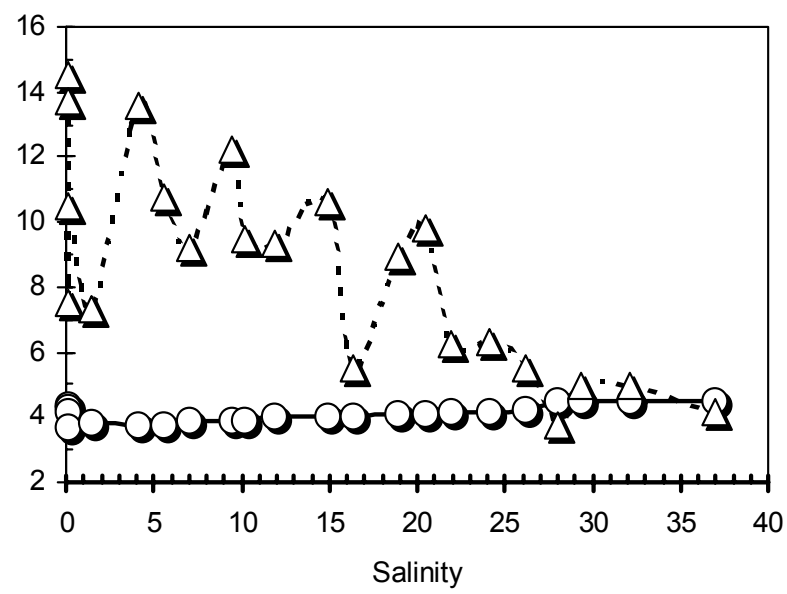

Figure 6. Simultaneous generation of ammonium (m mol/l) $(-\Delta-)$ and consumption of oxygen $(\mathrm{ml} / \mathrm{l})(-\mathbf{O}-)$ in the surface waters of the Manzanares river, Venezuela, during the months of the dry season of the year 1997.
Figure 5. Reduction of suspended material (SM) with salinity in estuarine waters of the Manzanares river, Venezuela, during the months of the dry season (-7-) and the wet season $(-\boldsymbol{\Delta}-)$ of the year 1997. 
Bol. Inst. Oceanogr. Venezuela, Univ. Oriente 41 (1\&2): 15-24 (2002); 7 Figs., 2Tabs.

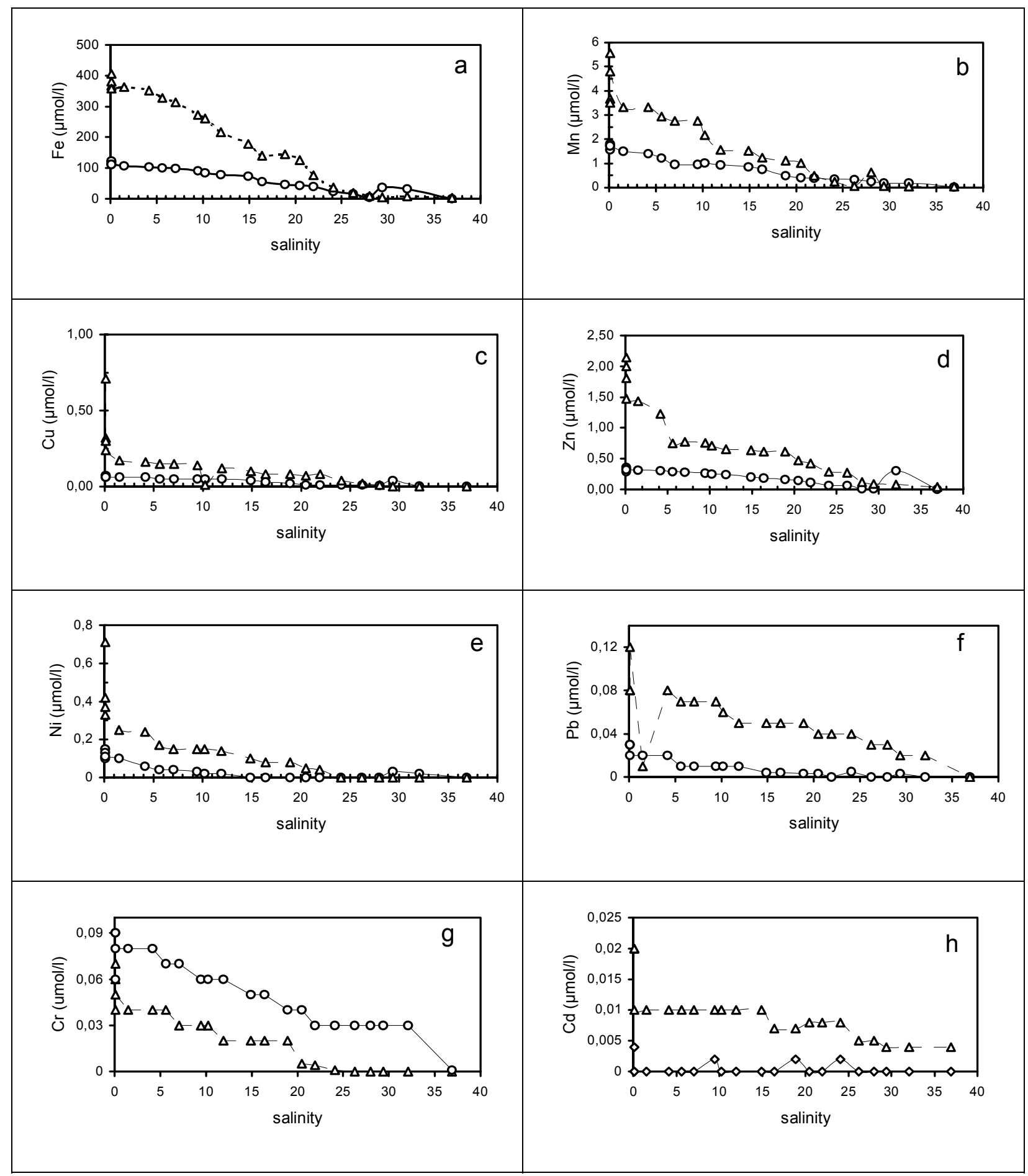

Figure 7. Diagrams of mixing of the studied metals in the suspended fraction as a function of salinity in the estuarine waters of the Manzanares river, Venezuela, during the months of low water (-o-) and of high water (August: -- $\boldsymbol{\Delta}$-) of the year 1997. 
For the dissolved metals $\mathrm{Fe}, \mathrm{Mn}, \mathrm{Zn}, \mathrm{Cu}$ and $\mathrm{Ni}$, on the other hand, it was found that concentrations increased in the dry season, $\mathrm{Cr}, \mathrm{Pb}$ and $\mathrm{Cd}$ not being detected in this phase. This increase of dissolved metals in the upstream extreme during the dry season may be due to processes of liberation of the metals from decomposed organic matter and/or diffusion from the river bed sediments, which processes are promoted by the higher temperature and the greater time of residence of the waters during this time.

The deposition of the heavy metals with the increase of salinity in the Manzanares river (Fig. 7a-7h) is associated with processes of flocculation and precipitation in the form of oxyhydroxides as the $\mathrm{pH}$ slowly increases from fresh to marine water values as a result of mixing, which generates an increase in dissolved basic salts (MÁrquez et al., 2000). The concentrations of all the metals found in this study are greatly above the limits prescribed by Venezuelan regulatory legislation for waters for human consumption and even for discharge to coastal bodies of water.

The results obtained could indicate a significant impact upon the stability of not only the ecosystem of the Manzanares river but also that of the bay of Mochima (a reservoir of great biodiversity en Venezuela), inasmuch as the currents during the rainy season carry the waters of the river to that zone (Mora et al., 1967). These conclusions may indicate risk for the life of the aquatic biota and of the population situated in the margin of the Manzanares river. Moreover, the presence of such dissolved metals as $\mathrm{Fe}, \mathrm{Mn}, \mathrm{Zn}, \mathrm{Cu}$ and $\mathrm{Ni}$, together with $\mathrm{Pb}$ and $\mathrm{Cd}$, may well promote the availability of these elements for the biota of the ecosystem, which in turn may generate problems of bioaccumulation.

\section{CONCLUSIONS}

The waters of the Manzanares river show an evident degradation which is reflected in the low levels of oxygen, high levels of ammonium caused by the introduction and decomposition of residues of anthropogenic origin in the study zone, considerable concentrations of suspended material originated by the erosion of the soils in the higher drainage basin and levels of heavy metals which are above the values permitted by Venezuelan legislation for consumable waters and even for waters discharged into coastal bodies of water.

\section{ACKNOWLEDGEMENTS}

The authors thank the technical staff of the Departmento de Oceanografía of the Instituto Oceanográfico de Venezuela who helped in this study. We would like to thank also Dr. Loren Lockwood for reviewing the manuscript. This research was granted partially by the Consejo de Investigación de la Universidad de Oriente, through projects C.I.5-18010693/94 and CI-5-019-006921/94.

\section{REFERENCES}

Aguilera De León, L. \& L. Rojas . 1976. La Ictiofauna del complejo hidrográfico del río Manzanares, Edo. Sucre. Venezuela. Lagena 37-38: 23-35.

Aguilera, D., R. Lastra, \& M. Betancourt. 1985. Rescate del río Manzanares. Informe preliminar de la comisión nombrada por el Consejo Municipal del Distrito Sucre (Estado Sucre) sobre la conservación, mejoramiento y defensa del Manzanares, su cuenca y el área bajo su influencia. Cumaná: Venezuela. pp. 46.

Alvarado, E. 1979. Algunas observaciones sobre las descargas de nitrógeno en el río Manzanares, Cumaná, Venezuela. Trabajo de grado de M.Sc. en Ciencias Marinas. Inst. Oceanogr. Venezuela, Universidad de Oriente, Cumaná, Venezuela. pp. 53.

.1976. Algunas observaciones sobre la concentración de fosfatos en el río Manzanares. Tesis de Pregrado. Lic. Educación mención Química,. Escuela de Humanidades y Educación. Universidad de Oriente, Cumaná, Venezuela. pp. 34.

Aminot, A \& Chhaussepied. 1983. Manual des analyses chimiques en milieu marin. Centre National Pour Lcexploitation des oceans (CNEXO)>BNDO/ Documentation. Francia. (pp. 335.

Cincin-SAin, W. 1993. Sustainable development and integrated coastal management. Ocean and coast Management 21: 11-43.

Elbaz-Poulichet, F., J. Garnier., M. Guan, J. Martin, \& A. Thomas. 1996. The conservative behavior of trace metals $(\mathrm{Cd}, \mathrm{Cu}, \mathrm{Ni}$ and $\mathrm{Pb})$ and as in the 
surface plume of stratified estuaries: Example of the Rhöne River (France). Estuar. Coast. and Shelf. Sc, 42: 280-310.

Emiliani, F. 1997. Los términos del deterioro ambiental: Contaminación, polución y eutrofización. Cartilla de difusión \# 10. Museo Provincial de Ciencias Naturales Florentino Ameghino, Argentina. pp. 6.

Fernández, E.1971. Algunos aspectos sobre la contaminación del río Manzanares por desechos industriales. Resumen IX reunión de Laboratorios. Marinos del Caribe. Cumaná: Venezuela. pp. 19.

.1973. Algunas observaciones sobre la contaminación de las aguas costeras de la ciudad de Cumaná, Venezuela. Bol. Inst. Oceanogr. Univ. Oriente 12 (1): $23-32$.

.1984. Contaminación de los ríos Guasdua y Manzanares. Estado Sucre, Venezuela. Bol. Inst. Oceanogr. Univ. Oriente 23 (1 - 2): 113 -128.

Godoy, G. 1991. Estudio espacio-temporal de los parámetros fisicoquímicos y biológicos en la zona estuarina del río Manzanares (Cumaná- Venezuela). Trab. Grado M.Sc. en Ciencias Marinas. IOV, Universidad de Oriente, Cumaná, Venezuela. pp. 185.

Greenber, A., L. Clesceri \& A. Eaton. 1992. Standard Methods for the Examination of Water and $W$ astewater, $18^{\text {th }}$ Edition. APHA-AHWA. USA. pp 3060 .

IABICHELlA, M. 1993. Evaluación bacteriológica del sector marino-costero San Luis-Guapo, Cumaná. Venezuela; según los criterios para las aguas de contacto humano total y parcial. Trab. Grado M.Sc. en Ciencias Marinas, IOV, Universidad de Oriente, Cumaná. Venezuela. pp. 300.

Koroleff, F. 1969. Direct determination of ammonia in natural water as indophenol blue. Int.Counc.Explor.Sea.C.M. 1969/C 9: 19-22.

Maloney, A. 1966. El delta del río Manzanares. Pasado, presente y futuro. Lagena 10: 3 -6.

León, I. 1995. Comportamiento y distribución de los metales pesados (Fe, Cu, Cd, Mn, Cr, Ni, Zn y $\mathrm{Pb}$ ) en la cuenca baja y pluma del río Manzanares (Cumaná - Venezuela). Trab. Grado M.Sc. en Ciencias Marinas. IOV, Universidad de Oriente, Cumaná, Venezuela. pp. 214.

, W. Senior \& G. Martínez, 1997. Comportamiento del hierro, cromo, cadmio y plomo total en las aguas superficiales del río Manzanares, Venezuela, durante los períodos de sequía y lluvia en el año 1994. Carib. Jour. Sci. 33 (1):105-107.

Márquez, A. 1997. Comportamiento y distribución de algunos metales pesados en fracciones disueltas $y$ particuladas en aguas superficiales del rio Manzanares. Edo. Sucre, Venezuela). Trab. Grado Lic. Química, Universidad de Oriente, Cumaná. Venezuela. pp. 141

W. Senior, \& G. Martínez 2000. Concentraciones y comportamiento de metales pesados en una zona estuarina de Venezuela. Interciencia 25 (6): 284-291.

Martínez, G. 1999. Especiación de metales pesados en la cuenca baja y pluma del río Manzanares, Edo. Sucre, Venequela. Trab. Grado M.Sc. en Ciencias Marinas. IOV. Universidad de Oriente, Cumaná, Venezuela. pp.160 .

. \& W. Senior 2001.- Especiación de metales pesados $(\mathrm{Cd}, \mathrm{Zn}, \mathrm{Cu}$ y $\mathrm{Cr}$ ) en el material en suspensión de la pluma del río Manzanares, Venezuela. Interciencia, 26 (2): 53-61.

Meybeck, M. 1982. Carbon, nitrogen and phosphorus transport by world rivers. Amer. Jour Sci. 288: 401-450.

Mora, C., M. López \& T. Okuda 1967. Algunas observaciones hidrobiológicas de las costas de Cumaná. Bol. Inst. Oceanogr. Univ. Oriente, 6 (2):303-327.

Olsen, R \& M. Sommerfeld 1973. A technique for extraction and storage of water samples for $\mathrm{Mn}$, $\mathrm{Cd}$ and $\mathrm{Pb}$ determination by atomic absorption spectroscopy. Atomic Absorption Newsletter 12 (6): $165-168$. 
SEnior, W \& G. Godoy 1991. Estudio fisicoquímico del río Manzanares (Cumaná-Venezuela). Bol. Inst. Oceanogr. Venequela Univ. Oriente 29 (1-2): 160 172.

.1994. Diagnóstico ambiental del río Manzanares. Informe técnico. Departamento de Oceanografía, Universidad de Oriente, Cumaná, Venezuela UDO. pp. 22.

RECIBIDO: 15 noviembre 2001

ACEPTAdo: 24 enero 2003
1995. Manual de Métodos de Análisis de Agua de Mar. Instituto Oceanografico. de Venezuela, Universidad de Oriente, Cumaná, Venezuela. pp. 22.

SonG, Y. \& G. Müller 1995. Biogeochemical cycling of nutrients and trace metals in anoxic freshwater sediments of the Neckar River. Germany. Mar. Freshwater. Res 46: 237-43. 